\title{
Factors inhibiting the psychological recovery process of children in conflict with the law
}

\author{
Putri Marlenny Puspitawati, ${ }^{1 *}$ Subandi, ${ }^{1}$ Maria Goretti Adiyanti, ${ }^{1}$ Eddy Omar Sharif \\ Hiariej, ${ }^{2}$ Solmaz Bulut ${ }^{3}$ \\ ${ }^{1}$ Faculty of Psychology, Universitas Gadjah Mada, Yogyakarta - Indonesia, ${ }^{2}$ Faculty of Law, Universitas Gadjah \\ Mada, Yogyakarta - Indonesia, ${ }^{3}$ Family and Children's Services, Tulsa, Oklahoma - United States
}

\begin{abstract}
Psychological assistance is crucial in recovering the psychological condition of children in conflict with the law. The City Government of Semarang, Indonesia has responded to this need with a school-based restorative justice program. This study aims to explore the factors that can hinder the psychological recovery process of children in conflict with the law during the implementation of the program. A qualitative approach was employed, based on case studies of three children in conflict with the law, with their significant others as participants. Case study data analysis techniques were employed, namely matching patterns, building explanations, finding model logic, and synthesizing cases. The results show that negative peer support, drug abuse, negative role models, emotional detachment, and negative stigma towards children in conflict with the law can be factors that hinder their psychological recovery process. The findings could provide the basis for practitioners in the preparation of psychological interventions that are relevant to the psychological recovery needs of children.
\end{abstract}

Keywords: psychological recovery; children in conflict with the law; restorative justice

\begin{abstract}
Abstrak: Pendampingan psikologis menjadi krusial dalam pemulihan kondisi psikologis anak yang berhadapan dengan hukum. Pemerintah Kota Semarang, Indonesia telah merespons kebutuhan ini dengan program keadilan restoratif berbasis sekolah. Penelitian ini bertujuan untuk menggali faktor-faktor yang dapat menghambat proses pemulihan psikologis anak yang berhadapan dengan hukum selama implementasi program keadilan restoratif berbasis sekolah. Penelitian ini menggunakan pendekatan kualitatif melalui metode studi kasus jamak dengan tiga anak yang berhadapan dengan hukum beserta significant others sebagai partisipan. Penulis menggunakan acuan teknik analisis data studi kasus, yakni mencocokkan pola, membangun penjelasan, menemukan logika model dan sintesis antar kasus. Hasil penelitian menunjukkan bahwa dukungan negatif teman sebaya, penyalahgunaan narkoba, adanya teladan negatif, emotional detachment, dan stigma negatif kepada anak yang berhadapan dengan hukum dapat menjadi faktor yang menyebabkan proses pemulihan psikologis menjadi terhambat. Temuan ini hendaknya menjadi landasan bagi para praktisi dalam penyusunan intervensi psikologis yang relevan dengan kebutuhan pemulihan psikologis anak.
\end{abstract}

Kata Kunci: pemulihan psikologis; anak yang berhadapan dengan hukum; keadilan restoratif

\footnotetext{
*Corresponding Author: Putri Marlenny Puspitawati (kakak_ciput@yahoo.com), Faculty of Psychology, Universitas Gadjah Mada, Jl. Sosio Humaniora Bulaksumur, Yogyakarta 55281-Indonesia.
} 


\section{Introduction}

The case of children involved in legal issues deserves serious attention. Based on data compiled from the Indonesian Child Protection Commission (KPAI), between 2011 and 2019 there were 11,492 cases of children involved in legal procedures, as victims, witnesses, and perpetrators. According to the Law of the Republic of Indonesia, Number 11 of 2012 concerning the Criminal Justice System for Children, the term 'child in conflict with the law' includes children who have infringed the law, those who are victims of criminal acts, and those who are witnesses of such acts. According to the law, children who are perpetrators of criminal acts are referred to as children in conflict with the law.

Based on article 1, paragraph (3) of Law of the Republic of Indonesia Number 11 of 2012 concerning the Criminal Justice System for Children, it is stated that children in conflict with the law are those aged over 12 and under 18, who are suspected of committing a criminal act. In 2018. the PPA Bareskrim Polri Unit recorded 1735 such children.

Based on their age range, this means that they are still at school. According to research by Puspitawaty, Adiyanti, and Minza (2019) on 34 junior high schools in Semarang City, there were at least 153 cases of children in conflict with the law. This fact is of course very concerning, considering that children still have a long future. Therefore, in accordance with the mandate of Law Number 11 of 2012 concerning the Juvenile Justice System, all children, including those in conflict with the law, must receive legal protection in the law enforcement process.

On the other hand, the formal legal process can cause trauma and psychological pressure on children (Kordi \& Ghufran, 2015). Juneman (2008) states that law enforcement can have consequences that are both therapeutic and antitherapeutic. Therefore, in the context of legal conflict experienced by children, it is important to ensure that law enforcement takes into account their psychological state and development.

The Indonesian government has responded to this need by adopting a new paradigm in the juvenile criminal system through the emergence of Law of the Republic of Indonesia Number 11 of 2012 concerning the Juvenile Criminal Justice System. This new paradigm is known as restorative justice.

Restorative justice is the process of involving the parties involved in violating the law in jointly identifying and coping damages in order to restore the situation as best as possible (Zehr, 2014). Restorative justice is based on the settlement of cases out of court through deliberations between children in conflict with the law, victims, families, and related parties to find solutions to the problems together.

According to Van Ness and Strong (2015), the main spirit of restorative justice is restoration. The recovery referred to is not only the recovery of victims from criminal acts, but also that of the perpetrators and the community. According to Van Ness and Strong (2015), a violation of the law does not only affect the victim, but also the community and the perpetrators of the crime themselves, especially with regard to psychological injury or harm. In fact, Roche (2003) emphasizes that the most serious losses that arise from crime are those related to emotional and psychological harm. Underwood and Washington (2016) state that children in conflict with the law can experience many mental health problems, 
such as emotional disorders, depression, anxiety disorders, self-control problems, and psychotic disorders.

In practice, children in conflict with the law in the restorative justice process are assisted at the Social Welfare Organizing Institution (LPKS), where efforts to improve their behavior and restore their psychological state are made. However, according to Abidin (2019), the results of this social rehabilitation process are still not optimal. Therefore, in consideration of this, the City of Semarang has developed a school-based restorative justice program that is expected to help overcome the problems of children in conflict with the law, especially those involving students at school.

The application of school-based restorative justice is a new concept in Indonesia, but it has been known and applied for a long time in various countries such as the United States, New Zealand, Australia, England, Spain, Austria, and other European countries since the early 2000s (Miers, 2001). In addition, several countries, such as Hong Kong and Malaysia, have also started implementing school-based restorative justice (Azam, 2016; Wong et al., 2011).

In practice, the school-based restorative justice program in Semarang City involves parties commonly related to violence, such as the victims, perpetrators, witnesses, teachers at school, and also the families of the children in conflict with the law. The program is facilitated by psychologists, advocates, and guidance and counseling teachers in each school. The program includes childfriendly mediation, psychological recovery courses, and the establishment of a restorative school climate. Specifically, in 2019 the psychological recovery program was attended by 30 children in conflict with the law. The program is intended to restore the psychological state and behavior of the children in conflict with the law.

Based on the observations, in the course of implementing the program, it was found that some children did not show improvement in their behavior or psychological state. These preliminary findings raise questions about the nature of the mechanisms that are hindering the process of the psychological recovery of the children in the context of the application of restorative justice.

Discussion of psychological recovery itself in the psychology literature elaborates more on the psychological recovery process in a clinical or mental health context, such as clinical recovery models (Robert Paul Liberman et al., 2002), rehabilitative recovery models (Anthony \& Liberman, 1992), and personal psychological recovery models. (Andresen et al., 2011). All of these models address psychological recovery in adults with mental disorders. On the other hand, it is difficult to find scientific literature that elaborates the psychological recovery process in children, especially those in conflict with the law.

Therefore, considering the findings explained above on the obstacles to the psychological recovery process of children in conflict with the law, which occur during the process of implementing school-based restorative justice, this study intends to explore in-depth the factors which can hinder this process. The research is relevant, considering that there is no real databased picture in the field of these factors. In addition, theoretical references are needed for program evaluation and planning, as well as for the development of concepts related to the psychological recovery of children in conflict with the law. 


\section{Method}

Qualitative research was conducted, with multiple case studies. According to Yin (2015), a case study aims to explore a case in a real context, specifically performed when the boundaries between a phenomenon and its context cannot be clearly explained. This research was conducted with reference to the phases of multiple case study research of Rashid (2019), which consists of the foundation phase, the pre-field phase, the field phase, and the reporting phase.

The study participants were three children in conflict with the law, namely AD, DF, and TG. They were junior high school students in Semarang City who were undergoing a school-based restorative justice program. They had been involved in criminal cases including physical violence and bullying.

The selection of the research participants was based on the results of the observations. There is evidence of the progress of the recovery of children in conflict with the law in the city of Semarang when participating in such a schoolbased restorative justice program. Based on the observations, it was found that three participants indicated that there were obstacles to their psychological recovery during the program, including recidivism, the slow process of improving behavior, and unstable emotional responses.

Data mining was also conducted on those close to them, namely the parents and teachers of each participant. The research data were collected through in-depth interviews and observations. Data analysis was performed by referring to the case study data analysis technique of Yin (2015), namely by matching patterns, building explanations, finding model logic, and synthesizing cases.
The research team generated category coding based on the data collected from the field research.

The credibility of the research was ensured in line with Cresswell (2015), including triangulation of the research data, peer debriefing, and respondent validation of the research participants.

\section{Results}

After the data had been collected through the in-depth interviews and participant observation, they were analyzed, which resulted in research findings in the form of factors that hindered the participants' psychological recovery. However, before further explanation of the findings, profiles are given of the study participants, describing their case histories.

\section{Profile of Research Participants}

\section{Participant Profile AD}

The first participant, namely $\mathrm{AD}$, was a boy aged 14 years who was now in grade 3 junior high school. He grew up and developed in a broken and conflicted family and was in conflict with the law because of repeatedly committing physical violence in the form of beating his schoolmates. His actions resulted in experiencing physical injuries, trauma and having to move school. The case of $\mathrm{AD}$ was handled by the police, but considering that he was still a child, it was then resolved amicably outside the court. Cases involving $\mathrm{AD}$ were then handled using $\mathrm{a}$ restorative justice approach. He received psychological assistance to restore his psychiatric state and to improve his behavior.

During the school-based restorative justice program, $\mathrm{AD}$ created obstacles, with resistance, slow progress in improving his behavior, and repeated acts of violence. 


\section{Participant Profile SH}

The second participant, SH, was a 14-year-old girl in grade 2 at the first middle school. She was a child who had lived and grown up in a conflicted family environment. SH was known to have repeatedly committed several violations of the law, such as assault, extortion and fraud on her friends at school. Similar to the AD case, was also dealt with outside the court using a restorative justice approach. SH was also known to have experienced psychological problems due to conflicts with the law. She was once trapped in drug abuse and even committed self-harm by slashing her wrists. She is currently receiving psychological assistance to restore her psychological state and improve maladaptive behavior.

During the school-based restorative justice program, SH experienced several obstacles, such as psychological instability related to self-harm, repeated violence, and resistance from her family to be involved in the mediation process.

\section{Participant Profile TG}

The third participant was TG, a 14-year-old teenager who grew up and developed with a conflicted family background and in a broken home. TG was in conflict with the law by committing physical violence and being involved in drug abuse. His case was resolved through a restorative justice approach outside the formal court legal process. TG was under considerable stress during his conflict with the law. At its peak, he experienced stigma and stress, to the point of quitting school and running away from home. When this research was conducted, TG was undergoing a psychological assistance process to recover his psychological state and behavior.
During his school-based restorative justice program, TG experienced several obstacles, such as repetition of the drug abuse, violence, and school refusal.

\section{Inhibiting Factors for Psychological Recovery}

The research analysis produced data categories which then formed five broad themes. These emerging themes showed the obstacles during the psychological recovery process of the study participants. The five factors are detailed below.

\section{Negative peer support}

Negative peer support refers to how peers provided support and influenced the participants' negative behavior and lawlessness, which could develop and hinder the improvement in their behavior. The effects referred to include, among others, being involved in fights and brawls between friends; the existence of defense against law by gang members; being actively involved in gang activities; and emotional closeness between gang members. This was found in $\mathrm{AD}, \mathrm{SH}$, and TG. The participants received social support for their negative behavior from their peers or gang groups.

In the case of the SH, her bullying behavior was influenced by her gang friends. The intervention was conducted by separating her from these friends. Based on information from $\mathrm{SH}$, friends in the same gang often helped cover up violations of the law. This was expressed by SH as follows: "My gang friends are all considerate; if I'm naughty they cover it up." (SH_W2_210-212)

In the case of TG, the form of negative support from peers can be seen from support for being involved in violent acts such as bullying and fights. 
This was not only verbal support, but also support in the form of taking part in the violence. During an interview session with the researcher, TG stated that:

"The one who went forward to them was me because the one who had a problem was me. My friends just followed behind and escorted me when I was attacked. My friends also love to fight. They all escorted me when I was attacked. Fight in front of the school or inside the school, but he refuses. I said if you don't dare, just wear a skirt." (TG_W1_34-45)

\section{Negative role models}

Negative role models refer to how the individual's social environment, including the family, reflects negative behavior, which can be used as a reference behavior for participants. Individual negative behaviors that were found included alcohol consumption, aggressive behavior, engaging in illegal street racing, and dropping out of education. This was found to be particularly pronounced in SH and TG. The parental figures in the participants' families did not play a good role; instead, they were perceived by the children as an example of negative behavior, such as drunkenness and violence.

$\mathrm{SH}$ received negative role models from their parents, both from the father and mother, who had a history of drinking alcohol. They had also displayed violent behavior since childhood. However, based on the study findings, SH preferred to make her father a role model rather than his mother. Unfortunately, apart from having a history of drinking alcohol, SH's father also had a history of dropping out of school, using school fees for other purposes, being involved in violence, and living on the street. Moreover, SH also witnessed violent behavior by her parents since she was a child. During her childhood, SH's father did not hesitate to beat and abuse his wife. Since kindergarten, it was common for the participants to see their mothers getting drunk. This was a negative role model for $\mathrm{SH}$. The following is one of the responses from the participants to support this:

"My father used to be antisocial. Singing on the train. Told to go to college but even used the tuition fee to get drunk. Then he said he was busking on the train. Yes, of course, my father was getting slapped. My father and uncle can get drunk at home. In kindergarten, I often saw my mother come home at night drunk." (SH_W1_351-353, 478, 491-492)

On the other hand, TG's father had impulsive behavior. Since childhood, TG had paid attention to his father's behavior. He said that he chose to avoid his father out of fear of being affected by his emotions and anger. In addition to his father, TG's uncle also had a history of violence in the form of brawls, and was even processed by the police when he was at junior high school. This behavior was copied by TG and it was evident that during the interview process, he was very enthusiastic about talking about the negative behavior of his father and uncle, as shown in the following statement:

"My uncle also kept on fighting at the PGRI Junior High School here. He damaged a car until all the glass shattered and then he was arrested by the police. Then he fought again and cut people and then ran away. Then he was wanted by the police. He found my father at his friend's house. The house is located in a remote area. Then my uncle was picked up and sent to Bogor. Imprisoned there 8 months then returned. My uncle was violent." (TG_W3_65-72,)

\section{Drug Abuse}

Drug abuse refers to the children's history of drug consumption. This was found in the 
participants, including $\mathrm{AD}$, whose drug taking, namely methamphetamine, was undertaken together with friends in a gang. Through the interview and observation data collection, it was found that SH took ecstasy. She showed a photo of her and her friends taking drugs. Apart from consuming yellow ecstasy, $\mathrm{SH}$ and his friends also took anti-motion sickness drugs, consuming them excessively. "I joined, "ngantimo" (consuming drugs), I used to also "ngantimo." (SH_W1_42842).

Unlike SH, who had not reached the addiction stage and had only consumed drugs a few times at a friend's invitation, TG had been taking class 1 drugs for a relatively long time, 4-5 months. This was established from his answer to the researcher's question on how long he had been taking this class 1 type of drug: "5 months, if not 4 months, then 5 months." (TG_W2_37-38)

\section{Emotional detachment}

Emotional detachment refers to a participant's inability to be involved in meaningful emotional interactions with family members, teachers, and peers. This inability can be seen from the unconducive communication between family members. In addition, it is also evident from the pattern of aggressive interactions; no initiative to engage in communication; lack of respect; grudges; a lack of emotional closeness; and negative perceptions of parental figures.

Emotional detachment in the mother figure was prominent in the cases of $\mathrm{AD}$ and $\mathrm{SH}$. For $\mathrm{SH}$, communication that is less intimate and conducive can be seen in her perception of her mother's image. According to SH, her mother was very emotional, and she believed that her mother loved her younger siblings more than her. They fought every day. Often SH ran away from home for several days. Her inability to have a meaningful relationship with her mother was mirrored by her relationship with teachers at school. She had a negative perception of them, especially in the guidance and counseling provided. SH thought that guidance and counseling teachers always brought up cases of delinquency, even though the problems had been resolved. This made her always avoid meeting guidance and counseling teachers, as shown by the following statement:

"Want to get away. It is better not to pass the class because there is Mrs. C. When it is time for her class, I will be lazy. The way she spoke hurts me. She always brought up my mistakes. I'm getting lazy." (SH_W1_615-616, 667-668)

Just like $\mathrm{SH}, \mathrm{AD}$ was also emotionally detached from her mother, as can be seen from the following answer:

"Her stepmother is having a baby. She rarely goes to her mother's house, maybe she is disappointed. How come a child that age already has a lot of problems. Until now, if her mother is trying to find her, she may refuse to meet her mother." (AD_SO2_W1_52-54, 150152)

\section{Negative stigma in children}

Negative stigma in children indicates the existence of a negative label given by the social environment to them. This could be in the form of labeling a child as naughty; suspecting them of being a perpetrator of an abusive behavior; labeling them as a criminal; and blaming them continuously for the mistakes they have made. One of the negative stigmas suffered by the participants was from teachers at school. For AD, the stigma experienced was in the form of suspicion. In addition to being frequently 
suspected, $A D$ was stigmatized for being a stubborn child who dared to fight the teacher's words, as expressed by AD:

"Then what's the deal with the teacher? "I'm just checking. Here I am your parent". "Even my real parents never checked what I did, so how come the teacher did." "It means your parents don't care." At school, I was very famous for being naughty. That is, if the teachers advised me, I would even advise them back." (AD_W2_105-109)

TG also suffered negative stigma from his parents. He was labeled as a naughty child and had bad behavior. This made him no longer have trust in his parents and was always viewed negatively in the school environment. TG stated:

"How would people want to believe in me. I can't be trusted. Because they labeled me as not a good person, they didn't need to be defended." (TG_W2_12-13,).

These stigmas are strengthened, perceived, and become an inherent part of the research participants as children in conflict with the law.

\section{Discussion}

The study has found that there are at least five factors that can hinder the psychological recovery process of children in conflict with the law, namely negative peer support, drug abuse, negative role models, emotional detachment, and negative stigma. This section will discuss how these factors can hinder the recovery process. How the factors can interact with each other in hindering psychological recovery will also be discussed.

\section{Peer Gangs, Crime, and Obstacles to Recovery}

Negative peer support is one of the factors that hinder the psychological recovery of children in conflict with the law. One of the examples of negative support that was most pronounced among the study participants was involvement with gangs. According to many studies, such involvement correlates with criminality in children. A meta-analysis of 179 studies by Pyrooz, Jillian, Scott, and Jun (2015) concluded that regardless of the various methods and measures employed, gang involvement was associated with crime rates in adolescents. This scientific fact shows that involvement with gangs is closely related to crime.

The impact of gang involvement can even last until the age of 20 to 30, causing economic hardship, mental health problems, family problems, and continued crime (Gilman, Hill, \& Hawkins, 2014; Krohn, Jeffrey, Thornberry, Lizotte, \& Chu, 2011). In the findings of our study, all the participants were found to be negatively affected by peer gangs. Even in the case of TG, emotional attachment with gang members had been formed, so that whatever the gang recommends, in the end becomes a reference for him.

According to researchers, negative peer support can hinder the process of improving the behavior and psychological state of children with special needs, as it facilitates their continued involvement in criminal acts. Scientific findings show that juvenile crime and delinquency increase when children are actively involved in and are influenced by gangs, compared to when they had no such involvement (Haviland \& Nagin, 2005; Melde \& Esbensen, 2014). An analysis by (Thornberry et al., 2018) found that reducing the risk of children's involvement in gangs was one of the important keys in reducing the crime rate among young people. 
Drug Abuse and Psychological Impacts for Children in Conflict with the Law

Another factor that can hinder psychological recovery is drug abuse. This makes sense, because through involvement in gangs, the members will be able to support and influence each other in drug abuse. According to (Thornberry et al., 2018), such abuse also relates to the involvement of young people in gangs. This implies that drug abuse also interacts with negative peer support through this involvement. For AD, SH, and TG, drug consumption grew out of curiosity and eventually became a form of existence among their peers.

Drug abuse is scientifically associated with bad psychological effects. Chassin (2008) found that drug addiction in children in conflict with the law (juvenile offenders) could create serious mental health problems. In addition, studies also suggest that children who abuse drugs are more likely to re-engage in legal violations and are less likely to experience resistance from criminal acts (Young et al., 2007). Therefore, it can be argued that drug abuse can hinder the psychological recovery process because it can make children's psychological problems worse, and on the other hand also increase the risk of children once again being in conflict with the law.

\section{Negative Examples and Traumatic Experiences}

Another factor that hindered the participants' psychological recovery was the presence of negative behavior examples. The most prominent of these were examples of violence in the family where the children lived. Their exposure to scenes of violence perpetrated by parents and immediate family could be a traumatic experience for them. Sacks, Murphey, and Moore (2014) state that events that have the potential to become traumatic for children can cause mental health and well-being problems, that are difficult to eradicate and last a long time. According to several studies, such traumatic experiences correlate with acts of lawlessness in adolescence (Fox et al., 2015; Weaver et al., 2008; Wolff et al,, 2017). The findings of the study indicate that the three participants did indeed grow up and develop in family ecosystems full of conflict, a culture of violence, and broken homes. In another sense, the significant member of the family became a bad role model for the participants. According to researchers, a negative role model and its psychological impact on children can be factors that hinder their recovery because the impact of exposure to violence can last into adulthood.

Emotional Detachment: The Absence of Meaningful Attachment

Another factor that appears in the findings of this study is the emotional detachment of children from their social environment, especially from their families. It is agued that this factor is related to the previous factor, namely negative family member role models, especially with regard to children's exposure to violence. As previously explained, violence can cause trauma, so that the emotional bond between the child and the parent is tenuous. Even in the case of $\mathrm{AD}$, the lack of emotional attachment to the mother figure made it very difficult for him to have confidence in the older people. Regarding emotional detachment, Gottfredson and Hirschi (1990) had proposed in social control theory that attachment to parents and peers was a barrier to delinquent behavior. In other words, according to this theory repeated acts of violence committed by children in conflict with the law are motivated by the absence of 
meaningful attachment between them and other people. Therefore, researchers assess that emotional detachment can hinder behavior improvement in the psychological recovery process for children with special needs.

Stigma: Negative Labels Impeding Recovery

Another factor that can hinder the process of psychological recovery in children in conflict with the law is negative stigma. Being labeled or stigmatized has a considerable effect on how individuals perceive themselves (Link et al., 1989). This is very relevant to the condition of the study participants, who were stigmatized by their surroundings, resulting in a negative assessment of themselves and their ability to change. Inzlicht (2012) state that stigma can lead to poor mental health, maladaptive behavior, and difficulties in joining society. Therefore, it is concluded that the negative stigma that the social environment placed on the participants was an obstacle to their psychological recovery process.
Based on the research findings, it can be concluded that negative peer support, drug abuse, negative role models, emotional detachment, and negative stigma are factors that hinder psychological recovery in children in conflict with the law, in this case the study participants.

The limitations of this study concern the depth of exploration and the number of participants. This is related to the sensitive topic, especially concerning children. The results of the study are expected to be a reference for professionals involved in rehabilitation and psychological assistance in arranging relevant interventions and to consider the obstacles experienced by children. This is crucial because it relates to the recovery process for children who are conflict with the law. In addition, it is hoped that this research will become a trigger for further research, considering that the topic of the psychology of children in conflict with the law is still in its infancy in the academic realm in Indonesia.[]

\section{Conclusion}

\section{References}

Abidin, Z. (2019). Rehabilitasi sosial anak berhadapan dengan hukum di lembaga Indonesia Safe House di Malang. Sosio Konsepsia, 8(2), 1-13. https://doi.org/10.33007/ska.v8i2.1463

Andresen, R., Oades, L., \& Caputi, P. (2011). Psychological recovery beyond mental illness. WileyBlackwell.

Anthony, W. A., \& Liberman, R. P. (1992). Principles and practice of psychiatric rehabilitation. In R. P. Liberman (Ed.), Handbook of Psychiatric Rehabilitation (pp. 1-29). MacMillan.

Azam, S. B. M. (2016). Amalan restoraktif dalam program perlindungan dan pemulihan remaja hamil luar nikah di Malaysia. The Malaysian Journal of Social Administration, 12(1), 100-135. https://doi.org/10.22452/mjsa.vol12no1.5

Chassin, L. (2008). Juvenile justice and substance use. The Future of Children, 18(2), 165-183. https://doi.org/10.1353/foc.0.0017

Creswell, J. W. (2015). Riset pendidikan: Perencanaan, pelaksanaan, dan evaluasi riset kualitatif \& kuantitatif. Pustaka Pelajar. 
Fox, B. H., Perez, N., Cass, E., Baglivio, M. T., \& Epps, N. (2015). Trauma changes everything: Examining the relationship between adverse childhood experiences and serious, violent and chronic juvenile offenders. Child Abuse \& Neglect, 46, 163-173. https://doi.org/10.1016/j.chiabu.2015.01.011

Gilman, A. B., Hill, K. G., \& Hawkins, J. D. (2014). Long-term consequences of adolescent gang membership for adult functioning. American Journal of Public Health, 104(5), 938-945. https://doi.org/10.2105/AJPH.2013.301821

Gottfredson, M. R., \& Hirschi, T. (1990). A general theory of crime. Stanford University Press.

Haviland, A. M., \& Nagin, D. S. (2005). Causal inferences with group based trajectory models. Psychometrika, 70(3), 557-578. https://doi.org/10.1007/s11336-004-1261-y

Inzlicht, M., Tullett, A. M., \& Gutsell, J. N. (2012). Stereotype threat spillover: The short-and long-term effects of coping with threats to social identity. In M. Inzlicht \& T. Schmader (Eds.), Stereotype threat: Theory, process, and application. Oxford University Press.

Juneman, A. (2008). Yurisprudensi terapeutik: Peran integratif psikologi dalam proses hukum untuk melayani kesejahteraan pribadi (well-being) klien hukum. Jurnal Kajian Ilmiah Universitas Bhayangkara Jakarta Raya, 9(3), 908-922. https://doi.org/10.31234/osf.io/cfg4u

Kordi, K., \& H, M. G. (2015). Durhaka kepada anak: Refleksi mengenai hak dan perlindungan anak. Pustaka Baru Press.

Krohn, M. D., Ward, J. T., Thornberry, T. P., Lizotte, A. J., \& Chu, R. (2011). The cascading effects of adolescent gang involvement across the life course. Criminology, 49(4), 991-1028. https://doi.org/10.1111/j.1745-9125.2011.00250.x

Liberman, Robert Paul, Kopelowicz, A., Ventura, J., \& Gutkind, D. (2002). Operational criteria and factors related to recovery from schizophrenia. International Review of Psychiatry, 14(4), 256-272. https://doi.org/10.1080/0954026021000016905

Link, B. G., Cullen, F. T., Struening, E., Shrout, P. E., \& Dohrenwend, B. P. (1989). A modified labeling theory approach to mental disorders: An empirical assessment. American Sociological Review, 54(3), 400-423. https://doi.org/10.2307/2095613

Melde, C., \& Esbensen, F.-A. (2014). The relative impact of gang status transitions. Journal of Research in Crime and Delinquency, 51(3), 349-376. https://doi.org/10.1177/0022427813507059

Miers, D. (2001). An international review of restorative justice. Home Office, Policing and Reducing Crime Unit.

Puspitawati, P. M., Adiyanti, M. G., \& Minza, M. W. (2019). Pertimbangan logis guru terhadap UndangUndang Republik Indonesia Nomor 11 Tahun 2012 dalam konteks pemulihan anak yang berkonflik dengan hukum. Universitas Gadjah Mada, Yogyakarta.

Pyrooz, D. C., Turanovic, J. J., Decker, S. H., \& Wu, J. (2016). Taking stock of the relationship between gang membership and offending. Criminal Justice and Behavior, 43(3), 365-397. https://doi.org/10.1177/0093854815605528

Rashid, Y., Rashid, A., Warraich, M. A., Sabir, S. S., \& Waseem, A. (2019). Case study method: A step-bystep guide for business researchers. International Journal of Qualitative Methods, 18, 160940691986242. https://doi.org/10.1177/1609406919862424

Roche, D. (2003). Accountability in restorative justice. Oxford University Press.

Sacks, V., Murphey, D., \& Moore, K. (2014). Adverse childhood experiences: National and state level prevalence. In Research Brief - Child Trends. https://doi.org/10.13140/2.1.1193.8087 
Thornberry, T. P., Kearley, B., Gottfredson, D. C., Slothower, M. P., Devlin, D. N., \& Fader, J. J. (2018). Reducing crime among youth at risk for gang involvement. Criminology \& Public Policy, 17(4), 953-989. https://doi.org/10.1111/1745-9133.12395

Underwood, L., \& Washington, A. (2016). Mental illness and juvenile offenders. International Journal of Environmental Research and Public Health, 13(2), 228. https://doi.org/10.3390/ijerph13020228

Van Ness, D. W., \& Strong, K. H. (2015). Restoring justice: An introduction to restorative justice. Routledge.

Weaver, C. M., Borkowski, J. G., \& Whitman, T. L. (2008). Violence breeds violence: Childhood exposure and adolescent conduct problems. Journal of Community Psychology, 36(1), 96-112. https://doi.org/10.1002/jcop.20219

Wolff, K. T., Baglivio, M. T., \& Piquero, A. R. (2017). The relationship between adverse childhood experiences and recidivism in a sample of juvenile offenders in Community-Based Treatment. International Journal of Offender Therapy and Comparative Criminology, 61(11), 1210-1242. https://doi.org/10.1177/0306624X15613992

Wong, D. S. W., Cheng, C. H. K., Ngan, R. M. H., \& Ma, S. K. (2011). Program effectiveness of a restorative whole-school approach for tackling school bullying in Hong Kong. International Journal of Offender Therapy and Comparative Criminology, 55(6), 846-862. https://doi.org/10.1177/0306624X10374638

Yin, R. K. (2015). Case study research: Design and methods (5th ed.). Sage.

Young, D. W., Dembo, R., \& Henderson, C. E. (2007). A national survey of substance abuse treatment for juvenile offenders. Journal of Substance Abuse Treatment, 32(3), 255-266. https://doi.org/10.1016/j.jsat.2006.12.018

Zehr, H. (2014). The little book of restorative justice. Good Books. 